a total grant of $£ 1,900$ for work on a new type of Wilson cloud chamber in the form of a resonant microwave cavity in which time marks are applied to the particle tracks at equal intervals (see p. 746 of this issue of Nature). The Paul Instrument Fund Committee, composed of representatives of the Royal Society, the Physical Society, the Institute of Physics and the Institution of Electrical Engineers, was set up in 1945 "to receive applications from British subjects who are research workers in Great Britain for grants for the design, construction and maintenance of novel, unusual or much improved types of physical instruments and apparatus for investigations in pure or applied physical science".

\section{Rockefeller Institute Quarterly}

THE Rockefeller Institute for Medical Research is now issuing, primarily for present and former members of the Institute, the Rockefeller Institute Quarterly, the first.issue being dated March 1957. It is intended to provide background information of the current work of the Institute and its plans for future development. The first issue contains a brief account of the research programme of the Population Council, the Medical Division and Laboratory of which have been housed at the Institute since September 1954. The Laboratory also assists in the diagnosis of reproductive defects in men by examining testicular biopsies and has developed a technique for determining genetic sex by examining somatic cells such as those in the skin or on oral smears. There is also a Demographic Division which seeks to promote the scientific study of population problems. The Abby Aldrich Rockefeller Hall, which is nearing completion, is to provide a social and residential centre for visiting scientists from all over the world and for the Institute faculty. Extensive changes in the facilities of the Institute buildings, which are nearing completion, will provide for Dr. F. Lipmann's biochemistry laboratory and laboratories for Dr. E. L. Tatum's work on the biochemical genetics of micro-organisms. There are also notes on the Institute's joint programme with the National Academy of Sciences and National Research Council to assist Hungarian scholars, and on the establishment of the post of Administrative Associate for Information Services, as well as lists of appointments and distinctions.

\section{Information Service on Psychopharmacology}

A clearing house of information on psychopharmacology is being established by the Psychopharmacology Service Center of the U.S. National Institute of Mental Health. An extensive collection of the literature in this field, including pharmacological, clinical, behavioural and experimental studies of the ataraxic, psychotomimetic and other centrally acting drugs, will be classified and coded to enable the staff to answer a wide variety of technical and scientific questions. As soon as enough materials have been assembled, the Center plans to offer bibliographical and reference services as well as the preparation of critical and analytical reviews of special topics in the field. In order to accelerate the growth of the literature collection, the Center invites persons working in the field to provide three copies of any papers that deal with their work-whether reprints, pre-publication manuscripts, progress reports, informal mimeographed reports, papers read at meetings, or abstracts. Letters outlining work in progress would also be welcome. Any restrictions that authors may wish to place on the Center's use of their papers will be strictly observed. All materials should be addressed to the Technical Information Unit, Psychopharmacology Service Center, National Institute of Mental Health, 8719 Colesville Road, Silver Spring, Maryland.

\section{Search for and use of Natural Resources}

Impact of March 1957 contains an article by J. Gray, "Technology and the Quest for Materials", which is a timely corrective to the common tendency to over-simplify the issues in controversy on population and resources and the implication of technical changes. Mr. Gray emphasizes the need to plan research ahead rather than continue to rely on the haphazard reactions of private enterprise, but he points out that while all the available evidence suggests that the demand for materials will continue to rise sharply in the next few decades, the urgency of this need is still debatable. The great increase in the consumption of leading metals since 1880 is due to the industrialization of a handful of countries : ninetenths or more of the world's pig iron, copper, lead, zinc and tin, outside the Communist countries, are consumed in Europe, the United States, Canada, New Zealand, Australia and Japan, but it is probable that the under-developed countries will only slowly affect world demand. To keep production per head of population at the present level, however, requires an increase of nearly 3 per cent por annum in Latin America, 2 per cent in Asia and Africa, and at least 1.5 per cent in North America, Australasia and the U.S.S.R. Mr. Gray suggests that among the problems which most need examination in this context, regardless of cost or immediate return, are substitutes for coal and base metals, the use of alloying metals, new sources of plastics, new fuels for road and air transport and the scope for little-used materials. As regards conservation of resources, the two most obvious steps are to inspire and stimulate interest in design, and the systematic use of scrap. More serious is the need for research on methods of ore dressing and extraction, but while there is room for more conscious planning of prospecting, there are difficulties both on the national and the international plane, chiefly financial and nationalistic. The main hope of increasing the supply of agricultural raw materials lies in increasing the yield per acre.

\section{Information and Communication}

A PAPER by Dr. H. Coblans on "New Methods and Techniques for the Communication of Knowledge" in the Unesco Bulletin for Libraries of July (Paris : Unesco) is a first step in a long-term programme of study, experiment and development in a field which is becoming a principal interest of Unesco. Starting from discussions and conclusions reached at the Royal Society Scientific Information Conference, the Unesco International Conference on Science Abstract. ing and the Unesco Conference on the Improvement of Bibliographical Services, Dr. Coblans considers first the new techniques and particularly their use by the Gmelin-Institut für anorganische Chemie, the Centre National de la Recherche Scientifique (Paris) and the Chemical--Biological Centre, Washington; he then suggests that costing studies for definite subjectfields on an operational basis should be stimulated in the major countries in which mechanical selectors 